\title{
PENGARUH PEMANFAATAN TEKNOLOGI INFORMASI DAN SISTEM PENGENDALIAN INTERNAL PEMERINTAH TERHADAP KUALITAS LAPORAN KEUANGAN PEMERINTAH DAERAH DENGAN PENATAUSAHAAN ASET TETAP SEBAGAI VARIABEL INTERVENING (Studi pada BPKA Kota Bandung)
}

\author{
Faesal Fazlurahman, Nunuy Nur Afiah, Ivan Yudianto* \\ Program Magister Akuntansi Universitas Padjadjaran \\ *e-mail: ffazlurahman8@gmail.com
}

DiPublikasi: 01/01/2021

http://dx.doi.org/10.22225/kr.11.2.1154.190-196

\begin{abstract}
The purpose of this study was to examine the effect of the use of information technology (IT) and the government's internal control system (SPIP) on the quality of local government financial statements (LKPD) by administering fixed assets as an intervening variable. the determination of the sample is determined by simple random sampling with the Slovin formula. The data source is primary data from the results of the questionnaire distributed and processed by path analysis. This study resulted in SPIP and the administration of fixed assets partially and simultaneously had a positive and significant effect on the quality of LKPD. However, the partial use of IT has a positive but not significant effect on the quality of LKPD. Then the partial and simultaneous use of IT and SPIP has a significant positive effect on the administration of fixed assets. In addition, the administration of fixed assets proved to be able to partially mediate the effect of the use of IT and SPIP on the quality of LKPD.

Keywords: quality of LKPD, administration of fixed assets, use of IT, SPIP.

Abstrak

Tujuan penelitian ini untuk menguji pengaruh pemanfaatan teknologi informasi (TI) dan sistem pengendalian internal pemerintah (SPIP) terhadap kualitas laporan keuangan pemerintah daerah (LKPD) dengan penatausahaan aset tetap sebagai variabel intervening. Penentuan sampel ditentukan oleh simple random sampling dengan rumus slovin. Sumber data berupa data primer dari hasil kuesioner yang disebar dan diolah dengan path analysis. Penelitian ini menghasilkan SPIP dan penatausahaan aset tetap secara parsial dan simultan berpengaruh positif dan signifikan terhadap kualitas LKPD. Namun pemanfaatan TI secara parsial berpengaruh positif tetapi tidak signifikan terhadap kualitas LKPD. Kemudian pemanfaatan TI dan SPIP secara parsial dan simultan berpengaruh positif signifikan terhadap penatausahaan aset tetap. Selain itu, penatausahaan aset tetap terbukti mampu memediasi secara parsial pengaruh pemanfaatan TI dan SPIP terhadap kualitas LKPD.
\end{abstract}

Kata Kunci : kualitas LKPD, penatausahaan aset tetap, pemanfaatan TI, SPIP.

\section{PENDAHULUAN}

Pemerintahan pada tiap - tiap daerah di Indonesia terus berupaya memperbaiki kualitas dari penyajian Laporan Keuangan Pemerintah Daerah (LKPD) yang telah disusunnya. Penyusunan LKPD menandakan adanya akuntabilitas pengelolaan keuangan kepada publik. Oleh karenanya, laporan keuangan harus menyajikan informasi dengan karakteristik kualitatif yaitu relevan, andal, dapat dibandingkan dan dapat dipahami (Mahmudi, 2016). Indikasi semakin berkualitasnya pengelolaan keuangan daerah dapat ditandai dengan semakin banyaknya perolehan opini Wajar Tanpa Pengecualian (WTP) atas penilaian LKPD yang dikeluarkan Badan Pemeriksa Keuangan (BPK) melalui hasil pemeriksaannya. Opini WTP merupakan salah satu poin penting yang menjadi tolak ukur transparansi keuangan daerah yang dilakukan dengan wajar, bebas dari salah saji material, serta selaras dengan peraturan keuangan.

Pemerintah kota Bandung sebagai ibukota Provinsi Jawa Barat, untuk pertama kalinya menyandang opini WTP pada Tahun 2019 atas hasil pemeriksaan BPK pada LKPD tahun anggaran 2018. Diraihnya opini WTP yang pertama ini tentunya bukan tanpa meningggalkan catatan-catatan masalah dari BPK. Catatan-catan 
tersebut tercantum dalam Laporan Hasil Pemeriksaan (LHP) BPK atas LKPD Kota Bandung Tahun Anggaran 2018. Sehingga Pemerintah Kota Bandung masih memiliki kewajiban untuk menyelesaikan semua permasalahan yang tercantum dalam LKPDnya agar menghasilkan LKPD yang lebih berkualitas.

Salah satu hambatan utama pemerintah Kota Bandung dalam perjuangan meraih opini WTP ini adalah terkait dengan penatausahaan aset. Sekretaris Daerah Pemkot Bandung Ema Sumarna mengungkapkan bahwa aset itu tadi Kepala BPKA (Badan Pengelola Keuangan dan Aset) total ada di angka 20 triliun (rupiah) lebih. Sampai ke 11 triliun turun ke angka 1,2 triliun sampai 678 miliar sampai ke 376 miliar ditarget harus di bawah 100 miliar turun lagi harus dibawah 50 miliar. Alhamdulillah akhirnya mentok di angka 23 miliar (Hafil, 2019). Sehingga hal tersebut masih menjadi tantangan tersendiri bagi Pemerintah Kota Bandung dalam menyelesaikan seluruh masalah aset khususnya dalam penatausahaan aset yang lebih baik.

Atas dasar LHP BPK terkait LKPD Kota Bandung Tahun Anggaran 2018 diketahui Pemerintah Kota Bandung memiliki beberapa permasalahan penatausahaan aset tetap yang menjadi pengecualian dalam opini LKPD Tahun 2017 yang akhirnya berpengaruh pada LKPDnya. Terdapat dua permasalahan utama aset tetap yang belum sepenuhnya terselesaikan dalam LKPD Tahun anggaran 2018 yaitu pertama, terkait dengan kewajaran penilaian aset yang tidak diyakini kewajarannya ditemukan nilai aset tetap yang masih belum ditindaklanjuti yaitu gedung dan bangunan senilai Rp. 11.061.163.330,00 dan jalan, jaringan, dan irigasi, senilai Rp. 31.090.650,00. Kedua, terkait daftar rincian aset tanpa informasi lengkap dan ditemukan nilai aset tetap masih belum ditindaklanjuti yaitu gedung dan bangunan senilai Rp. 352.623.400,00, peralatan dan mesin senilai Rp. 2.069.419.509,00 serta jalan,

\section{TINJAUAN PUSTAKA}

\section{Agency Theory}

Agency theory dapat diterapkan pada hampir semua entitas. Teori ini dapat diimplementasikan pada entitas publik, dimana dinyatakan bahwa negara demokrasi modern mengacu pada serangkaian hubungan antara prinsipal dengan agen (Lane 2000) Aoency theory dapat diounakan jaringan, dan irigasi senilai Rp. 5.269.100.357,00.

Permasalahan penatausahaan aset tetap yang ada dalam LKPD dapat disebabkan oleh belum maksimalnya pemanfaatan teknologi informasi (TI) yang dilakukan oleh Pemerintah Kota Bandung. Keberhasilan teknologi informasi diharapkan mampu menghasilkan informasi nilai aset yang sebenarnya dan dapat meminimalisir kesalahan pencatatan yang terjadi, Sehingga pemanfaatan teknologi informasi yang diterapkan secara maksimal dapat berdampak positif pada kualitas LKPD. Apabila dapat meminimalisir kesalahan pencatatan dan penyajian laporan keuangan dapat ditindak cepat, maka pembuatan laporan keuangan dapat semakin andal dan relevan sehingga semakin baik pemanfaatan TI, maka kualitas laporan keuangan semakin meningkat (Ardianto, R., Eforis, 2019).

Dalam menunjang penatausahaan aset juga tentunya harus ditunjang oleh pelaksanaan Sistem Pengendalian Internal Pemerintah (SPIP) yang berjalan sesuai peraturan. Permasalahan penatausahaan aset masih menjadi temuan di berbagai daerah dan merupakan kendala dalam melaksanakan pengelolaan BMD secara optimal, disebabkan lemahnya pengendalian internal yang dilakukan oleh pemerintah daerah dan belum sepenuhnya mematuhi peraturan yang berlaku (Kurniati, E., Asmony, T., \& Santoso, 2017). Selain itu, pemerintah harus memiliki SPIP yang andal agar mampu mencegah setiap penyimpangan yang terjadi saat ini dan berakibat kerugian keuangan daerah.

Berdasarkan uraian tersebut, maka penulis dapat mengidentifikasi permasalahan diantaranya : (1) Bagaimana pengaruh pemanfaatan TI, SPIP, dan penatausahaan aset tetap atas kualitas LKPD. (2) Bagaimana pengaruh pemanfaatan TI dan SPIP atas penatausahaan aset tetap. (3) Bagaimana pengaruh pemanfaatan TI dan SPIP terhadap kualitas LKPD melalui penatausahaan aset tetap sebagai mediasi.

dalam melakukan identifikasi kombinasi sistem informasi dan kontrak kerja yang akan memaksimalkan fungsi manfaat prinsipal, dan kendala-kendala perilaku yang muncul dari kepentingan agen (Raharjo, 2007).

Apabila pemerintah ingin memaksimalkan fungsi dan manfaat informasi yang disampaikan kepada masyarakat (prinsipal) maka pengelolaan 
keuangan dalam bentuk laporan keuangan dan aset harus benar serta berkualitas. Oleh karena itu, agency theory digunakan oleh penulis sebagai landasan teori atas variabel yang diajukan yaitu pemanfaatan TI dan SPIP dalam memperbaiki penatausahaan aset tetap yang akhirnya berpengaruh positif pada kualitas LKPD.

\section{Stewardship Theory}

Stewardship Theory memiliki dasar psikologi dan sosiologi yang dirancang mampu menjelaskan situasi dimana manajer sebagai steward dan bertindak sesuai kepentingan pemilik (Donaldson, L., \& Davis, 1991). Hal penting dalam stewardship theory adalah manajer menyelaraskan tujuannya sesuai dengan tujuan Prinsipal namun bukan berarti steward tidak memiliki kebutuhan (Raharjo, 2007). Dalam pengelolaan aset daerah, Pemerintah selaku steward menginginkan penyelenggaraan yang baik atas pengelolaan keuangan dan aset, sehingga dapat dipergunakan untuk melayani masyarakat. Sebagai pihak yang diberikan kepercayaan, maka pemerintah wajib mempertanggungjawabkan pengelolaan aset kepada masyarakat dalam bentuk LKPD yang berkualitas. LKPD yang berkualitas dapat dihasilkan dari pemanfaatan TI yang maksimal dan SPIP yang baik, serta penatausahaan aset yang sesuai dengan peraturan.

\section{Pengaruh Pemanfaatan TI Terhadap Kualitas LKPD}

Pemanfaatan TI memiliki peranan yang sangat penting dalam mempermudah dan mempercepat proses kerja dalam penyusunan laporan keuangan. Pelaporan keuangan yang optimal dan andal ditunjang dengan pemanfaatan TI yang baik akan berdampak pada laporan yang mudah disusun, diproses, disimpan untuk kualitas hasil data yang akurat, relevan dan tepat waktu, serta mudah diinformasikan dan diakses oleh seluruh masyarakat (Putra, R., Azlina., Safitri, 2017). Pernyataan tersebut sesuai dengan beberapa hasil penelitian diantaranya (Alminanda, P., 2018) yang memastikan pemanfaatan TI mempengaruhi kualitas LKPD pada Pemkab Bantul. SPIP berpengaruh secara signifikan terhadap kualitas LKPD pada Badan Pengelolaan Keuangan dan Aset Daerah (BPKAD) di Lombok. Sehingga kualitas LKPD diharapkan dapat semakin ditingkatkan dengan hadirnya teknologi yang semakin berkembang saat ini.
H1 : adanya pengaruh positif signifikan pemanfaatan TI terhadap kualitas LKPD.

\section{Pengaruh SPIP Terhadap Kualitas LKPD}

Peningkatan kualitas LKPD membutuhkan penerapan SPIP yang dapat memastikan seluruh penyelenggaraan kegiatan dapat terlaksana dengan efektif. SPIP yang telah ditetapkan, tetapi belum efektif, berakibat pada kualitas pelaporan keuangan yang tidak memuaskan (Nurlis, \& Yudiati, 2017). Pengaruh SPIP terhadap kualitas LKPD didukung oleh beberapa penelitian diantaranya (Ekayanti, S., Rifa'i, A, 2017) yang memastikan SPIP mempengaruhi kualitas LKPD pada Pemkab Bengkalis. Mene (2017) yang memastikan SPIP mempengaruhi secara positif signifikan terhadap kualitas LKPD pada Pemkab Halmahera Utara. (Anggriawan, F., Yudianto, 2018) yang memastikan SPIP mempengaruhi secara positif signifikan terhadap kualitas LKPD pada Pemkab Bandung Barat. Hal tersebut menunjukan bahwa SPIP memiliki peranan yang sangat penting dalam meningkatkan kualitas LKPD pada Pemerintah Daerah.

H2 : adanya pengaruh positif signifikan SPIP terhadap kualitas LKPD.

\section{Pengaruh Penatausahaan Aset Tetap Terhadap Kualitas LKPD}

Dalam merealisasikan LKPD yang lebih berkualitas, diperlukan berbagai tahapan dan proses kerja yang benar, salah satunya dalam tahapan penatausahaan aset yang meliputi tahap pembukuan, inventarisasi, dan pelaporan aset. peningkatan kualitas laporan keuangan dapat dilakukan dengan memperbaiki inventarisasi aset terutama aspek pembukuan dan pengadministrasian aset (Mansur, 2018) menyatakan bahwa. Pernyataan tersebut terbukti dalam penelitian (Trisnani, E. D., Dimyati, M., \& Paramu, 2018) yang memastikan bahwa penatausahaan aset tetap berpengaruh secara signifikan terhadap kualitas LKPD. Selain itu, (Febrianti, 2016) mengatakan bahwa penatausahaan aset tetap memiliki pengaruh secara signifikan terhadap kualitas LKPD.

H3 : adanya pengaruh positif signifikan penatausahaan aset tetap terhadap kualitas LKPD.

\section{Pengaruh Pemanfaatan TI Terhadap} Penatausahaan Aset Tetap

Teknologi informasi bermanfaat bagi pengguna untuk melakukan evaluasi penyelenggaraan kegiatan suatu entitas pelaporan 
dalam periode pelaporan, sehingga memudahkan fungsi perencanaan, pengelolaan dan pengendalian atas seluruh aset, kewajiban dan ekuitas dana pemerintah (Muda, I., 2019). Penggunaan teknologi informasi terkait manajemen aset daerah dianggap memiliki fleksibilitas, mudah dipelajari, mudah digunakan, dan mudah berinteraksi dengan kondisi sistem yang berbasis online (Goutama, E., 2019). Hal tersebut mengindikasikan jika teknologi informasi dimanfaatkan semakin baik dalam penyusunan laporan BMD maka akan cenderung meningkatkan kualitas laporan BMD yang dihasilkan (Subrata, I. W., Yasa, G. W., \& Astika, 2018). Hal ini sesuai dengan (Wahyuni, R., Fadah., Tobing, 2018) yang menyatakan pemanfaatan TI berpengaruh positif signifikan terhadap penatausahaan aset tetap. Sehingga pemanfaatan TI yang digunakan secara maksimal maka penatausahaan aset tetap dapat berjalan dengan baik.

H4 : adanya pengaruh positif signifikan pemanfaatan TI terhadap penatausahaan aset tetap.

Pengaruh SPIP Terhadap Penatausahaan Aset Tetap

SPIP memiliki peranan penting dalam penyelenggaraan pengelolaan aset daerah. apabila laporan BMD ingin ditingkatkan kualitasnya, maka hendaknya Pemerintah lebih mengefektifkan implementasi unsur-unsur SPIP di lingkungan Pemda untuk mengontrol dan mencegah penyimpangan terjadi dalam pengelolaan BMD (Subrata, I. W., Yasa, G. W., \& Astika, 2018). Pernyataan tersebut didukung hasil penelitian (Subrata, I. W., Yasa, G. W., \& Astika, 2018); (Wahyuni, R., Fadah., Tobing, 2018); dan (Goutama, E., 2019) yang memastikan SPIP berpengaruh positif signifikan terhadap penatausahaan aset tetap. Sehingga pelaksanaan SPIP yang semakin sesuai dengan peraturan maka akan menghasilkan penatausahaan aset tetap yang lebih baik.

H5 : adanya pengaruh positif signifikan SPIP terhadap penatausahaan aset tetap.

Pengaruh Pemanfaatan TI Terhadap Kualitas LKPD Melalui Penatausahaan Aset Tetap

Salah satu unsur penting dalam mewujudkan LKPD yang berkualitas adalah dengan melaksanakan penatausahaan aset. Penatausahaan aset atau BMD bukan hanya sekedar administratif tetapi lebih dari upaya pengelola aset untuk meningkatkan efisiensi, efektivitas dan meningkatkan nilai tambah aset atau BMD itu sendiri (Rachmawati, R., Arwati., 2018). Sehingga pelaksanaan penatausahaan aset khususnya aset tetap menjadi proses kerja yang wajib dilaksanakan dengan benar karena biasanya nilai aset menjadi nilai akun terbesar dibanding akun lain dalam laporan keuangan.

Pelaksanaan penatausahaan aset tetap yang benar tentunya harus ditunjang dengan pemanfaatan TI yang maksimal. Baiknya pemanfaatan TI dapat meningkatkan kualitas pelaporan aset daerah sekaligus meningkatkan kualitas pelaporan keuangan OPD. Sehingga idealnya teknologi informasi yang semakin canggih dapat dimanfaatkan secara maksimal untuk menunjang proses kerja dalam penatausahaan aset tetap sehingga hasil akhirnya kualitas LKPD diharapkan dapat semakin ditingkatkan.

H6 : adanya pengaruh positif signifikan pemanfaatan TI terhadap kualitas LKPD melalui penatausahaan aset tetap.

\section{Pengaruh SPIP Terhadap Kualitas LKPD Melalui Penatausahaan Aset Tetap}

Masalah LKPD yang sering kali menjadi catatan BPK dalam perolehan opini WTP adalah terkait dengan aset. Untuk mengatasi masalah tersebut diperlukan pengelolaan/manajemen aset yang baik. Manajemen aset daerah mempengaruhi pentingnya mewujudkan kualitas LKPD (Eriadi., Erlina., 2018). Pengelolaan aset yang baik memerlukan sistem pengendalian yang berjalan secara benar. Darise berpendapat bahwa diperlukan suatu sistem yang dapat memberi keyakinan memadai dalam mengelola aset daerah secara utuh, sehingga pelaksanaan kegiatan instansi pemerintah dapat mencapai tujuan secara efektif dan efesien, melaporkan pengelolaan keuangan secara andal, mengamankan aset dan mendorong ketaatan terhadap peraturan perundang-undangan, Sistem ini dikenal dengan sistem pengendalian intern (Mainar., Darwanis., Abdullah, 2017). Sehingga meningkatkan kualitas LKPD yang diharapkan dapat semakin meningkat, maka diperlukan penatausahaan aset yang benar dan sistem pengendalian internal yang mampu mengendalikan penyelenggaraan pemerintahan.

H7 : adanya pengaruh positif signifikan SPIP terhadap kualitas LKPD melalui penatausahaan aset tetap. 


\section{III}

\section{- METODE PENELITIAN}

Jenis penelitian yang digunakan yaitu dengan pendekatan kuantitatif dan metode deskriptif. Populasi target adalah Pegawai BPKA Pemkot Bandung yang memiliki kewenangan dalam menangani pelaporan keuangan dan pengelolaan aset sebanyak 45 orang. Teknik sampling penelitian yaitu simple random sampling dengan jumlah responden ditentukan dengan menggunakan rumus Slovin sebanyak 39 orang. Data dikumpulkan dengan kuesioner yang diserahkan langsung kepada resoponden terkait variabel yang diuji. Variabel dalam penelitian terdiri variabel eksogen yaitu pemanfaatan TI dan SPIP, variabel intervenig yaitu penatausahaan aset tetap, dan variabel endogen yaitu kualitas LKPD.

Variabel pemanfaatan TI adalah penilaian responden terhadap pemanfaatan teknologi informasi meliputi : proses kerja secara elektronik, pengolahan data dan informasi, sistem manajemen, serta perawatan dan pemeliharaan. Variabel pemanfaatan TI diukur dengan 9 indikator yang merujuk pada penelitian (Wardani, D., Andriyani, 2017) dan (Mardinan, T., Dahlan., 2018). SPIP adalah penilaian responden terhadap implementasi unsur SPIP meliputi : lingkungan pengendalian, kegiatan pengendalian, penilaian risiko, informasi dan komunikasi, serta pemantauan. Variabel SPIP diukur dengan 16 indikator yang merujuk pada PP Nomor 60 Tahun 2008. Variabel penatausahaan aset tetap yaitu penilaian responden atas tahap pembukuan, inventarisasi dan pelaporan aset tetap pada BPKA. Penatausahaan aset tetap diukur dengan 14 indikator yang merujuk pada Perda

\section{HASIL DAN PEMBAHASAN}

\section{Hasil Penelitian \\ Analisis Deskriptif}

Atas dasar analisa data pada 39 kuesioner yang telah diterima kembali diketahui variabel pemanfaatan TI memiliki nilai jawaban rata-rata (mean) total jumlah skor sebesar 36,72 dari total keseluruhan nilai sebesar 45, variabel SPIP memiliki nilai jawaban rata-rata (mean) total jumlah skor sebesar 65,23 dari total keseluruhan nilai sebesar 80, variabel penatausahaan aset tetap memiliki nilai jawaban rata-rata (mean) total jumlah
Kota Bandung Nomor 12 Tahun 2018. Variabel kualitas LKPD adalah penilaian responden terkait elemen kualitatif laporan keuangan yaitu relevan, andal, dapat dibandingkan, dan dapat dipahami. Variabel kualitas LKPD diukur dengan 12 indikator yang merujuk pada PP Nomor 71 Tahun 2010.

Penelitian ini ingin menganalisis dan memastikan pengaruh pemanfaatan TI dan SPIP terhadap penatausahaan aset tetap serta dampaknya pada kualitas LKPD. Teknik analisis data untuk mengolah dan menguji data yaitu dengan path analysis (analisis jalur). Path analysis dapat menganalisis pola hubungan antar variabel untuk mengetahui pengaruh langsung maupun tidak langsung seperangkat variabel independen terhadap variabel dependen. Namun, analisis jalur hanya mampu melakukan deteksi besaran pengaruhnya saja. Sedangkan untuk mengetahui signifikan atau tidaknya menggunakan uji sobel. Sebelum dilakukan analisis data dengan path analysis, maka perlu uji kualitas data diantaranya uji validitas dan reliabilitas data. Dalam Path analysis diperlukan prasyarat yang harus dipenuhi yaitu dengan melakukan uji asumsi klasik yang diantaranya uji normalitas, uji multikolinieritas, dan uji heteroskedastisitas. dan untuk menguji hipotesis pengaruh parsial maupun simultan antar variabel independen, dependen, dan intervening maka dilakukan pengujian hipotesis menggunakan uji t, uji koefisien determinasi, dan uji $F$. Keseluruhan analisis data dan uji hipotesis dibantu dengan alat hitung IBM SPSS Statistic 20.0.

sebesar 70, dan variabel Kualitas LKPD memiliki nilai jawaban rata-rata (mean) total jumlah skor sebesar 50,54 dari total keseluruhan nilai sebesar 60. Keseluruhan jawaban responden mayoritas memilih nilai yang mendekati angka 4 atau "setuju".

\section{Uji Kualitas Data}

Uji validitas menghasilkan nilai r-hitung dari masing-masing pernyataan kuesioner lebih besar dari r-tabel yakni 0,316 menunjukan semua pertanyaan pada semua variabel adalah valid. Selain itu__ _i relibilitas menghasilkan_ nilai_Cronbach 
Alpha lebih besar dari 0,7 pada setiap variabel menunjukan seluruh kuesioner disusun adalah reliabel atau andal.

\section{Uji Asumsi Klasik}

Uji normalitas dengan melihat tabel Kolmogorov-Smirnov dalam penelitian ini diketahui probabilitas (Asymp sig) $=0,941$ dan lebih besar dari > 0,05 menunjukan bahwa data residual penelitian berdistribusi normal dan dapat digunakan untuk melakukan uji hipotesis. Kemudian hasil uji multikolinieritas diketahui tidak ada variabel independen bernilai Tolerance kurang dari 0,10 dan hasil VIF diketahui tidak ada satu pun variabel independen yang bernilai VIF lebih dari 10 menunjukan bahwa tidak ada multikolinearitas antar variabel independen dalam model regresi. Dan hasil uji Glejser menunjukan tidak ada variabel independen yang signifikan secara statistik yang berpengaruh pada variabel dependen dengan melihat nilai absolut residual dan nilai signifikansi di atas 5\% menunjukan model regresi tidak terjadi heteroskedastistas.

\section{Uji Hipotesis}

Uji hipotesis dapat menentukan hipotesis diterima atau ditolak. Pengujian hipotesis yang diajukan dilakukan dengan cara uji statistik t, uji koefisien determinasi (R2) dan uji F.

\section{Hipotesis Pertama}

Pengujian hipotesis pertama untuk melihat variabel pemanfaatan TI (X1) dan SPIP (X2) yang berpengaruh parsial terhadap kualitas LKPD (Y). Selengkapnya uji $\mathrm{t}$ hipotesis pertama penelitian ini dengan melihat tabel 1 berikut :

Tabel 1

Hasil Uji Statistik t

\begin{tabular}{|c|c|c|c|c|c|c|}
\hline & \multirow[t]{2}{*}{ Model } & \multicolumn{2}{|c|}{$\begin{array}{c}\text { Unstandardiz } \\
\text { ed } \\
\text { Coefficients }\end{array}$} & \multirow{2}{*}{$\begin{array}{c}\begin{array}{c}\text { Standardize } \\
\mathrm{d} \\
\text { Coefficients }\end{array} \\
\text { Beta }\end{array}$} & \multirow[t]{2}{*}{$\mathrm{T}$} & \multirow[t]{2}{*}{ Sig. } \\
\hline & & B & $\begin{array}{l}\text { Std. } \\
\text { Error }\end{array}$ & & & \\
\hline \multirow{3}{*}{1} & (Constant) & $\begin{array}{r}1,50 \\
6\end{array}$ & 2,018 & & ,746 &, 460 \\
\hline & Pemanfaatan TI & ,229 &, 145 & , 178 & 1,586 &, 122 \\
\hline & SPIP & ,631 & ,091 &, 783 & 6,957 &, 000 \\
\hline
\end{tabular}

a. Dependent Variable: Kualitas LKPD

Sumber: Hasil Penelitian yang diolah, 2020

Tabel 1 menunjukkan bahwa adanya prosentase pengaruh langsung variabel bebas pengaruh positif namun tidak signifikan antara pemanfaatan TI (X1) dan SPIP (X2) yang semakin pemanfaatan TI terhadap kualitas LKPD. dekat hubungannya dengan variabel terikat melihat Sedangkan, variabel SPIP memiliki pengaruh positif variabel independen yaitu terhadap kualitas LKPD dan signifikan terhadap kualitas LKPD.

Selanjutnya, uji koefisien determinasi (R2) (Y). Hasil uji koefisien determinasi (R2) dapat dilihat pada tabel 2 berikut :

dilakukan untuk mengetahui seberapa besar

Tabel 2

Koefisien Determinasi (R2)

\begin{tabular}{|l|r|r|r|r|r|}
\hline Model & \multicolumn{1}{|c|}{$\mathrm{R}$} & & R Square & $\begin{array}{c}\text { Adjusted R } \\
\text { Square }\end{array}$ & $\begin{array}{c}\text { Std. Error of } \\
\text { the Estimate }\end{array}$ \\
\hline 1 &, $942^{\mathrm{a}}$ & &, 888 &, 882 & 2,06270 \\
\hline
\end{tabular}

a. Predictors: (Constant), SPIP, Pemanfaatan TI

b. Dependent Variable: Kualitas LKPD

Sumber: Hasil Penelitian yang diolah, 2020 
Hasil pengujian pada tabel 2 diketahui nilai adjusted $\mathrm{R}$ Square sebesar 0,882 yang berarti bahwa pemanfaatan TI (X1) dan SPIP (X2) mampu mempengaruhi kualitas LKPD (Y) sebesar 88,2\%, sedangkan $11,8 \%$ sisanya dipengaruhi oleh variabel lain diluar penelitian ini.
Kemudian untuk melihat pengaruh secara simultan pemanfaatan TI (X1) dan SPIP (X2) terhadap kualitas LKPD (Y) dilakukan dengan uji F. Selengkapnya dapat dilihat pada tabel 3 sebagai berikut :

Tabel 3

Hasil Uji Statistik F

\begin{tabular}{|l|r|r|r|r|r|}
\hline Model & \multicolumn{1}{|c|}{$\begin{array}{c}\text { Sum of } \\
\text { Squares }\end{array}$} & df & Mean Square & F & Sig. \\
\hline Regressio & 1211,599 & 2 & 605,799 & 142,38 &, $000^{\mathrm{b}}$ \\
$\begin{array}{l}\mathrm{n} \\
\text { Residual }\end{array}$ & 153,170 & 36 & 4,255 & & \\
& 1364,769 & 38 & & & \\
\hline
\end{tabular}

a. Dependent Variable: Kualitas LKPD

b. Predictors: (Constant), SPIP, Pemanfaatan TI

Sumber: Hasil Penelitian yang diolah, 2020

Atas pengujian statistik $\mathrm{F}$ dihasilkan nilai Signifikansi $F=0,000$ yang berarti $<\alpha=0,05$, sehingga hipotesis yang diajukan diterima dan $\mathrm{H} 0$ ditolak. Sehingga dapat dikatakan pemanfaatan TI (X1) dan SPIP (X2) secara simultan berpengaruh positif signifikan terhadap variabel kualitas LKPD (Y).

Setelah dilakukan pengujian pengujian hipotesis dengan cara uji t, uji koefisien determinasi, dan uji $\mathrm{F}$, sehingga dapat dibentuk persamaan regresi antar variabel yang diuji sebagai berikut :

$$
\begin{array}{r}
\mathrm{Y}=1,506+0,229 \mathrm{X} 1+ \\
0,631 \mathrm{X} 2 \ldots \ldots \ldots \ldots \ldots \ldots \ldots \ldots \ldots \ldots \ldots \ldots \ldots
\end{array}
$$

Hipotesis Kedua

Hipotesis Kedua Struktural I

Untuk menguji hipotesis kedua struktural I dilakukan agar dapat melihat variabel independen yaitu pemanfaatan TI (X1) dan SPIP (X2) yang berpengaruh secara parsial terhadap penatausahaan aset tetap (Z). Selengkapnya hasil uji t penelitian sebagai berikut :

Tabel 4

\begin{tabular}{|c|c|c|c|c|c|c|}
\hline & \multirow{2}{*}{ Model } & \multicolumn{2}{|c|}{$\begin{array}{l}\text { Unstandardized } \\
\text { Coefficients }\end{array}$} & \multirow{2}{*}{$\begin{array}{c}\begin{array}{c}\text { Standardize } \\
\mathrm{d} \\
\text { Coefficients }\end{array} \\
\text { Beta }\end{array}$} & \multirow[t]{2}{*}{$\mathrm{T}$} & \multirow[t]{2}{*}{ Sig. } \\
\hline & & B & $\begin{array}{l}\text { Std. } \\
\text { Error }\end{array}$ & & & \\
\hline & (Constant) & $\begin{array}{r}2,97 \\
7\end{array}$ & 2,991 & & ,995 & ,326 \\
\hline 1 & $\begin{array}{l}\text { Pemanfaatan } \\
\text { TI }\end{array}$ & ,491 & ,214 & ,336 & 2,291 & ,028 \\
\hline & SPIP & ,543 &, 134 & ,593 & 4,043 & ,000 \\
\hline
\end{tabular}

Hasil Uji Statistik t

a. Dependent Variable: Penatausahaan Aset Tetap

Sumber: Hasil Penelitian yang diolah, 2020

Tabel 4 memperlihatkan adanya pengaruh positif signifikan pemanfaatan TI terhadap 
penatausahaan aset tetap. Selain itu, adanya pengaruh positif signifikan variabel SPIP terhadap penatausahaan aset tetap.

Selanjutnya, uji koefisien determinasi (R2) dilakukan untuk mengetahui seberapa besar prosentase pengaruh langsung variabel bebas pemanfaatan TI (X1) dan SPIP (X2) yang semakin dekat hubungannya dengan variabel terikat penatausahaan aset tetap (Z). Selengkapnya uji koefisien determinasi (R2) sebagai berikut :

Tabel 5

Koefisien Determinasi (R2)

\begin{tabular}{|l|r|r|r|r|}
\hline Model & R & R Square & $\begin{array}{c}\text { Adjusted R } \\
\text { Square }\end{array}$ & $\begin{array}{c}\text { Std. Error of } \\
\text { the Estimate }\end{array}$ \\
\hline 1 &, $900^{\mathrm{a}}$ &, 810 &, 799 & 3,05752 \\
\hline
\end{tabular}

a. Predictors: (Constant), SPIP, Pemanfaatan TI

Sumber: Hasil Penelitian yang diolah, 2020

Hasil pengujian pada tabel 5 diketahui nilai adjusted $\mathrm{R}$ Square sebesar 0,799 yang berarti bahwa pemanfaatan TI (X1) dan SPIP (X2) mampu mempengaruhi variabel penatausahaan aset tetap (Z) sebesar 79,9\%, sementara 20,1\% merupakan variabel lain yang mempengaruhi penatausahaan aset tetap.

Kemudian untuk melihat pengaruh secara simultan pemanfaatan TI (X1) dan SPIP (X2) terhadap penatausahaan aset tetap (Z) dilakukan dengan uji F. Selengkapnya dapat dilihat pada tabel 4.6 sebagai berikut :

Tabel 6

Hasil Uji Statistik F

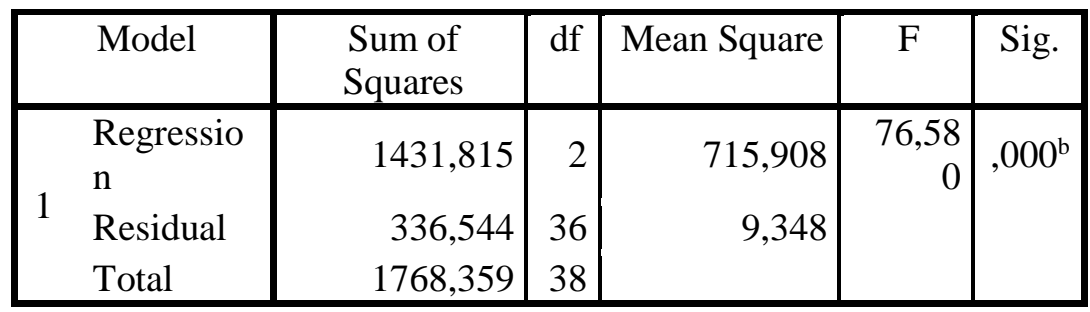

a. Dependent Variable: Penatausahaan Aset Tetap

b. Predictors: (Constant), SPIP, Pemanfaatan TI

Sumber: Hasil Penelitian yang diolah, 2020

Atas pengujian statistik $\mathrm{F}$ dihasilkan nilai Signifikansi $F=0,000<\alpha=0,05$, sehingga hipotesis yang diajukan diterima dan $\mathrm{H} 0$ ditolak. Sehingga dapat dikatakan pemanfaatan TI (X1) dan SPIP (X2) secara simultan berpengaruh positif signifikan terhadap terhadap variabel penatausahaan aset tetap (Z).

Setelah dilakukan pengujian pengujian hipotesis dengan cara uji t, uji koefisien determinasi, dan uji F, sehingga dapat dibentuk persamaan regresi antar variabel yang diuji sebagai berikut :

$$
\begin{array}{r}
Z=0,336 \mathrm{X} 1+0,593 \mathrm{X} 2+ \\
0,436 \ldots \ldots \ldots \ldots \ldots \ldots \ldots \ldots \ldots \ldots \ldots . . .
\end{array}
$$

Hipotesis Kedua Struktural II

Untuk menguji hipotesis kedua struktural II dilakukan untuk melihat variabel pemanfaatan TI (X1), SPIP (X2), dan penatausahaan aset tetap (Z) yang berpengaruh secara parsial terhadap kualitas LKPD (Y). Hasil uji t penelitian ini sebagai berikut : 
Tabel 7

Hasil Uji Statistik t

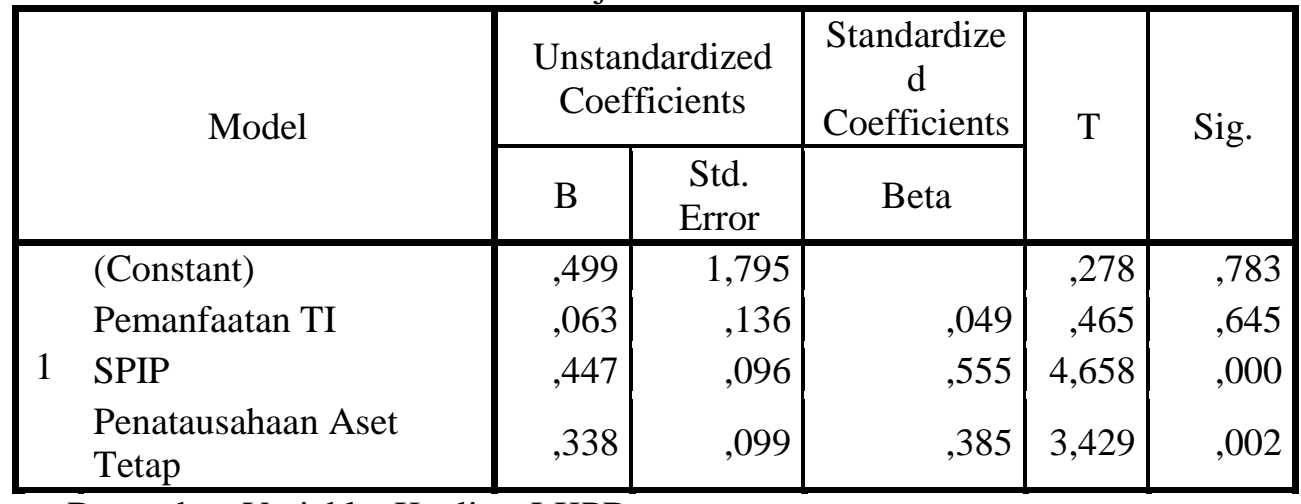

a. Dependent Variable: Kualitas LKPD

Sumber: Hasil Penelitian yang diolah, 2020

Tabel 7 memperlihatkan adanya pengaruh positif signifikan SPIP terhadap Kualitas LKPD. Selain itu, adanya pengaruh positif signifikan variabel penatausahaan aset tetap terhadap terhadap Kualitas LKPD. Sedangkan, variabel pemanfaatan TI memiliki pengaruh positif namun tidak signifikan terhadap Kualitas LKPD.

Selanjutnya, uji koefisien determinasi (R2) dilakukan untuk mengetahui seberapa besar prosentase pengaruh langsung variabel bebas pemanfaatan TI (X1), SPIP (X2), dan penatausahaan aset tetap (Z) yang semakin dekat hubungannya dengan variabel terikat Kualitas LKPD (Y). Selengkapnya uji koefisien determinasi (R2) sebagai berikut :

Tabel 8

Hasil Uji Determinasi (R2)

\begin{tabular}{|l|r|r|r|r|}
\hline Model & R & R Square & $\begin{array}{c}\text { Adjusted R } \\
\text { Square }\end{array}$ & $\begin{array}{c}\text { Std. Error of } \\
\text { the Estimate }\end{array}$ \\
\hline 1 &, $957^{\mathrm{a}}$ &, 916 &, 909 & 1,80992 \\
\hline
\end{tabular}

a. Predictors: (Constant), Penatausahaan Aset Tetap, Pemanfaatc

b. Dependent Variable: Kualitas LKPD

Sumber: Hasil Penelitian yang diolah, 2020

Berdasarkan hasil pengujian pada tabel 8 diketahui nilai adjusted R Square sebesar 0,909 yang berarti pemanfaatan TI (X1), SPIP (X2), dan penatausahaan aset tetap $(\mathrm{Z})$ mampu mempengaruhi variabel kualitas LKPD (Y) sebesar 90,9\% sedangkan $9,1 \%$ sisanya dipengaruhi oleh variabel lain diluar penelitian.

Kemudian untuk melihat pengaruh secara simultan pemanfaatan TI (X1) dan SPIP (X2) penatausahaan aset tetap (Z) terhadap kualitas LKPD (Y) dilakukan dengan uji F. Selengkapnya dapat dilihat pada tabel 9 sebagai berikut : 
Tabel 9

Hasil Uji Statistik F

\begin{tabular}{|c|c|c|c|c|c|c|}
\hline & Model & $\begin{array}{c}\text { Sum of } \\
\text { Squares }\end{array}$ & $\overline{d f}$ & Mean Square & $\mathrm{F}$ & Sig. \\
\hline \multirow{3}{*}{1} & Regression & 1250,115 & 3 & 416,705 & 127,20 &, $000^{\mathrm{b}}$ \\
\hline & Residual & 114,654 & 35 & 3,276 & & \\
\hline & Total & 1364,769 & 38 & & & \\
\hline
\end{tabular}

a. Dependent Variable: Kualitas LKPD

b. Predictors: (Constant), Penatausahaan Aset Tetap, Pemanfaatan TI, SPIP

Sumber: Hasil Penelitian yang diolah, 2020

Atas pengujian statistik $\mathrm{F}$ dihasilkan nilai Signifikansi $\mathrm{F}=0,000<\alpha=0,05$, sehingga hipotesis yang diajukan diterima dan $\mathrm{H} 0$ ditolak. Sehingga dapat dikatakan pemanfaatan TI (X1), SPIP (X2), dan penatausahaan aset tetap (Z) secara simultan berpengaruh positif signifikan terhadap terhadap variabel kualitas LKPD.

Setelah dilakukan pengujian pengujian hipotesis dengan cara uji t, uji koefisien determinasi, dan uji F, sehingga dapat dibentuk persamaan regresi antar variabel yang diuji sebagai berikut :

$$
\begin{gathered}
\mathrm{Y}=0,063 \mathrm{X} 1+0,447 \mathrm{X} 2+0,338 \mathrm{Z}+ \\
0,289 \ldots \ldots \ldots \ldots \ldots \ldots . .(4.3)
\end{gathered}
$$

Selanjutnya, untuk menguji hipotesis keenam dan ketujuh dilakukan dengan penghitungan tes sobel dengan rumus yang dikembangkan oleh Imam Ghozali (2011), sebagai berikut :

1. Uji signifikansi pengaruh tidak langsung Pemanfaatan TI (X1) terhadap Kualitas LKPD (Y) melalui Penatausahaan Aset Tetap (Z)

$a b=(0,491)(0,338)$

$a b=0,166$

$S_{a b}=\sqrt{b^{2} S_{a}^{2}+a^{2} S_{b}^{2}+S_{a}^{2} S_{b}^{2}}$

$S_{a b}=$ $\sqrt{(0,338)^{2}(0,214)^{2}+(0,491)^{2}(0,099)^{2}+(0,214)^{2}(0,099}$

$$
\begin{aligned}
& S_{a b}=0,089 \\
& \mathrm{t}=\frac{a b}{S_{a b}}=\frac{0,166}{0,089}=1,865
\end{aligned}
$$

Atas hasil perhitungan menghasilkan nilai $\mathrm{t}$ dibandingkan dengan nilai $\mathrm{t}$ tabel dengan jumlah $\mathrm{n}=39$ dan $\alpha=0,05$, diperoleh nilai $\mathrm{t}$ tabel sebesar 1,684. Ternyata nilai t hitung lebih besar dari nilai $\mathrm{t}$ tabel, yaitu $1,865>1,684$. Sehingga disimpulkan bahwa hipotesis ke-6 dalam penelitian ini diterima.

2. Uji signifikansi pengaruh tidak langsung sistem pengendalian internal pemerintah (X2) terhadap kualitas LKPD (Z) melalui Penatausahaan Aset Tetap (Y).

$a b=(0,543)(0,338)$

$a b=0,183$

$S_{a b}=\sqrt{b^{2} S_{a}^{2}+a^{2} S_{b}^{2}+S_{a}^{2} S_{b}^{2}}$

$S_{a b}=$ $\sqrt{(0,338)^{2}(0,134)^{2}+(0,543)^{2}(0,099)^{2}+(0,134)^{2}(0,099)^{2}}$

$S_{a b}=0,071$

$\mathrm{t}=\frac{a b}{S_{a b}}=\frac{0,193}{0,071}=2,577$

Atas hasil perhitungan menghasilkan nilai $\mathrm{t}$ dibandingkan dengan nilai $\mathrm{t}$ tabel dengan jumlah $\mathrm{n}=39$ dan $\alpha=0,05$, diperoleh nilai $\mathrm{t}$ tabel sebesar 1,684. Ternyata nilai t hitung lebih besar dari nilai t tabel, yaitu 2,577>1,684. Sehingga disimpulkan bahwa hipotesis ke-7 dalam penelitian ini diterima.

Atas hasil uji hipotesis ke-1 sampai ke-7 maka dapat diperoleh rangkuman pengujian hipotesis sebagai berikut : 
Tabel 10

Hasil Pengujian Hipotesis

\begin{tabular}{|l|c|}
\hline \multicolumn{1}{|c|}{ Hipotesis } & Hasil \\
\hline $\begin{array}{l}\text { : adanya pengaruh positif signifikan pemanfaatan TI terhadap } \\
\text { kualitas LKPD }\end{array}$ & Ditolak \\
\hline $\begin{array}{l}\text { H2 : adanya pengaruh positif signifikan SPIP terhadap kualitas } \\
\text { LKPD }\end{array}$ & Diterima \\
\hline $\begin{array}{l}\text { adanya pengaruh positif signifikan penatausahaan aset tetap } \\
\text { terhadap kualitas LKPD }\end{array}$ & Diterima \\
\hline $\begin{array}{l}\text { : adanya pengaruh positif signifikan pemanfaatan TI terhadap } \\
\text { penatausahaan aset tetap }\end{array}$ & Diterima \\
\hline $\begin{array}{l}\text { adanya pengaruh positif signifikan SPIP terhadap penatausahaan } \\
\text { aset tetap }\end{array}$ & Diterima \\
\hline $\begin{array}{l}: \text { adanya pengaruh positif signifikan pemanfaatan TI terhadap } \\
\text { kualitas LKPD melalui penatausahaan aset tetap }\end{array}$ & Diterima \\
\hline $\begin{array}{l}: \text { adanya pengaruh positif signifikan SPIP terhadap kualitas LKPD } \\
\text { melalui penatausahaan aset tetap }\end{array}$ & Diterima \\
\hline
\end{tabular}

Analisis Jalur

Analisis jalur dapat dikatakan sebagai pengembangan dari analisis regresi yang mampu mengukur hubungan kausalitas antar variabel.

Gambar 1

Diagram Jalur

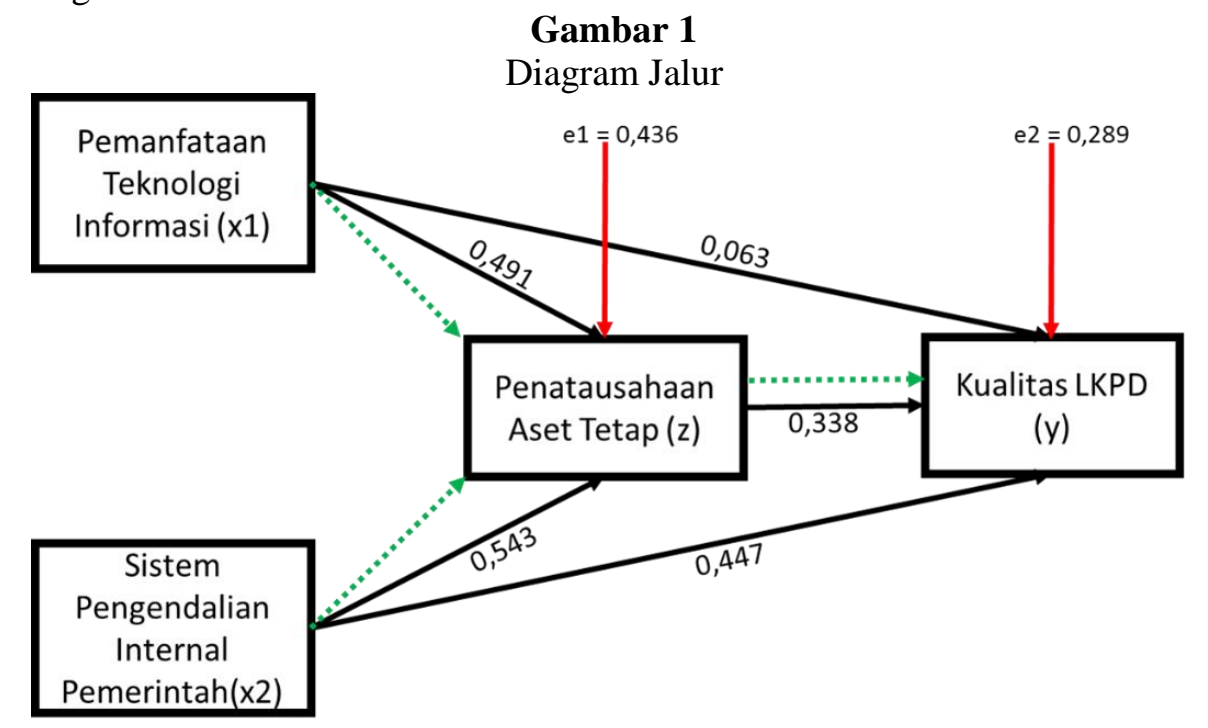

Sehingga model persamaan analisis jalur antar variabel dapat dilihat pada gambar 4.1 dan tabel 4.11 sebagai berikut: 
Tabel 11

Dekomposisi Pengaruh Variabel dalam Analisis Jalur

\begin{tabular}{|c|c|c|c|c|}
\hline No & $\begin{array}{c}\text { Pengaruh } \\
\text { Variabel } \\
\text { dalam } \\
\text { Analisis Jalur }\end{array}$ & $\begin{array}{c}\text { Pengaruh } \\
\text { Langsung } \\
\text { (Standardized } \\
\text { ) }\end{array}$ & $\begin{array}{c}\text { Pengaruh Tidak } \\
\text { Langsung } \\
\text { (Unstandardized } \\
\text { ) }\end{array}$ & $\begin{array}{c}\text { Pengaruh Total } \\
\text { (Total Effect) }\end{array}$ \\
\hline 1 & $\mathrm{X} 1->\mathrm{Y}$ & 0,049 & 0,129 & 0,178 \\
\hline 2 & $\mathrm{X} 2>\mathrm{Y}$ & 0,555 & 0,228 & 0,783 \\
\hline 3 & $\mathrm{Z}>\mathrm{Y}$ & 0,385 & - & 0,385 \\
\hline 4 & $\mathrm{X} 1>\mathrm{Z}$ & 0,336 & - & 0,336 \\
\hline 5 & $\mathrm{X} 2>\mathrm{Z}$ & 0,593 & - & 0,593 \\
\hline
\end{tabular}

Sumber: Hasil Penelitian yang diolah, 2020

\section{Pembahasan}

Pengaruh Pemanfaatan TI Terhadap Kualitas LKPD

Hasil uji hipotesis pertama dihasilkan variabel pemanfaatan TI berpengaruh positif namun tidak signifikan terhadap kualitas LKPD. Hasil tersebut menjelaskan meskipun pemanfaatan TI dapat membantu meningkatkan proses kerja, namun pemanfaatan TI tidak menjamin baiknya kualitas LKPD yang dihasilkan. Pemanfaatan TI dan fasilitas yang sudah optimal belum mampu mendorong secara signifikan peningkatan kualitas LKPD (Nurlis, \& Yudiati, 2017).

Hadirnya teknologi informasi yang terus berkembang hingga saat ini diharapkan dapat dimanfaatkan sebaik mungkin dalam menunjang produktivitas kerja, namun dibuktikan bahwa teknologi informasi yang tersedia pada pemerintah nyatanya masih belum dapat mempengaruhi secara signifikan terhadap kualitas LKPD yang dihasilkan. Hal tersebut didukung oleh hasil penelitian yang dilakukan oleh (Hasdiana, Hasang, 2018); dan (Fauziyah, 2019) menyatakan bahwa pemanfaatan TI tidak berpengaruh signifikan terhadap kualitas LKPD.

Pengaruh SPIP Terhadap Kualitas LKPD

Hasil uji hipotesis kedua dihasilkan variabel SPIP berpengaruh positif dan signifikan terhadap kualitas LKPD. Hasil tersebut menjelaskan bahwa semakin baik pelaksanaan SPIP sesuai dengan peraturan maka semakin baik pula kualitas LKPD yang dihasilkan oleh Pemerintah tersebut. Pengendalian intern terdiri atas kebijakan dan prosedur untuk mencapai sasaran dan menjamin atau menyediakan informasi keuangan yang andal, serta menjamin ditaatinya hukum dan peraturan yang berlaku (Nurillah, A., 2014).

SPIP apabila diterapkan sesuai dengan peraturan yang ditetapkan oleh Pemerintah dalam PP Nomor 60 Tahun 2008 maka akan menghasilkan penyelenggaraan kegiatan pemerintahan yang terkendali. SPIP diterapkan bertujuan memastikan tercapainya pengelolaan yang efektif dan efisien bersandar pada PP No. 60/2008, antara lain: lingkungan pengendalian, kegiatan pengendalian, penilaian resiko, informasi dan komunikasi serta pemantauan (Mene, R., Karamoy, H., Warongan, 2018). Hal tersebut didukung (Anggriawan, F., Yudianto, 2018); (Fhadillah, S., 2018); dan (Putra, R., Azlina., Safitri, 2017) yang menyatakan SPIP berpengaruh secara positif dan signifikan terhadap kualitas LKPD. Sehingga apabila SPIP dapat berjalan sesuai dengan peraturan maka akan menghasilkan kualitas LKPD yang lebih baik.

Pengaruh Penatausahaan Aset Tetap Terhadap Kualitas LKPD

Hasil uji hipotesis ketiga dihasilkan bahwa variabel penatausahaan aset tetap berpengaruh positif dan signifikan terhadap kualitas LKPD. Hasil tersebut menjelaskan bahwa penatausahaan aset tetap yang tertib akan meningkatkan kualitas LKPD, dan sebaliknya jika penatausahaan aset tetap kurang baik maka akan menurunkan kualitas LKPD. Hal ini bermakna bahwa pencatatan aset tetap pada Kartu Iinventaris Barang (KIB) secara lengkap dan akurat, inventarisasi yang optimal, dan pelaporan yang tepat waktu akan berdampak pada penyajian aset tetap di neraca dengan angka yang tepat dan akurat (Trisnani, E. D., Dimyati, M., \& Paramu, 2018).

Dalam Perda Kota Bandung No 12 Tahun 2018 bahwa Penatausahaan adalah rangkaian kegiatan yang meliputi pembukuan, inventarisasi, dan pelaporan BMD sesuai dengan ketentuan peraturan perundang-undangan. Dengan penyajian 
pembukuan BMD kedalam daftar barang pengguna dan kedalam kartu inventaris barang serta dalam daftar BMD akan memberikan kemudahan akses bagi para pengguna/kuasa pengguna barang yang melakukan pendaftaran dan pencatatan BMD ke dalam Daftar Barang Pengguna (DBP)/Daftar Barang Kuasa Pengguna (DBKP), kemudahan akses ini secara langsung akan membantu meningkatkan kualitas laporan keuangan (Febrianti, 2016). Hal tersebut didukung (Mansur, 2018); (Eriadi., Erlina., 2018); dan (Fhadillah, S., 2018); yang menyatakan bahwa penatausahaan aset tetap berpengaruh secara positif dan signifikan terhadap kualitas LKDP. Sehingga apabila penatausahaan aset tetap dapat berjalan sesuai dengan peraturan maka akan menghasilkan kualitas LKPD yang lebih baik.

Pengaruh Pemanfaatan TI Terhadap Penatausahaan Aset Tetap

Hasil uji hipotesis keempat dihasilkan variabel pemanfaatan TI berpengaruh positif dan signifikan atas penatausahaan aset tetap. Hasil tersebut menjelaskan bahwa semakin baik pemanfaatan TI maka semakin baik penatausahaan aset tetap tersebut. Salah satu upaya pengelolaan asset dengan pendekatan penggunaan teknologi sebagai solusi banyaknya aktivitas yang harus dijalankan oleh pengelola asset (Rachmawati, R., Arwati., 2018).

Pemanfataan teknologi informasi dapat dikatakan sebagai tindakan seseorang dalam memanfaatkan TI untuk kepentingan penyelesaian tugas dan peningkatan kinerjanya. Menurut Thompson pemanfaatan TI merupakan manfaat yang diharapkan pengguna sistem informasi dalam melakasanakan tugasnya atau perilaku dalam menggunakan teknologi pada saat melakukan pekerjaan (Wijana, 2007). Dengan tersedianya teknologi informasi diharapkan dapat dimanfaatkan sebaik mungkin dalam menunjang produktivitas kerja khususnya dalam pelaksanaan penatausahaan aset tetap. Hal tersebut didukung hasil penelitian (Subrata, I. W., Yasa, G. W., \& Astika, 2018); (Wahyuni, R., Fadah., Tobing, 2018); dan (Goutama, E., 2019) menyatakan bahwa pemanfaatan TI berpengaruh terhadap penatausahaan aset tetap. Semakin maksimal pemanfaatan TI yang digunakan, semakin baik juga tingkat penatausahaan aset tetap yang dilaksanakan oleh Pemerintah.

Pengaruh SPIP Terhadap Penatausahaan Aset Tetap Berdasarkan hasil uji hipotesis kelima dihasilkan bahwa variabel SPIP berpengaruh positif dan signifikan terhadap penatausahaan aset tetap. Hasil tersebut menjelaskan bahwa semakin baik pelaksanaan SPIP sesuai dengan peraturan maka semakin baik pula pelaksanaan penatausahaan aset tetap yang dilakukan oleh Pemerintah tersebut. dalam rangka meningkatkan kualitas laporan barang milik daerah, maka Pemerintah hendaknya lebih mengefektifkan implementasi unsur-unsur SPI di lingkungan Pemda untuk melakukan kontrol dan mencegah terjadinya penyimpangan dalam pengelolaan barang milik daerah (Subrata, I. W., Yasa, G. W., \& Astika, 2018).

SPIP merupakan sistem dengan kriteria-kriteria tertentu yang ditetapkan dalam Peraturan Pemerintah untuk melakukan pengendalian atas penyelenggaraan kegiatan pemerintahan. Dalam PP No. 60 Tahun 2008 dinyatakankan bahwa SPIP adalah proses yang integral pada tindakan dan kegiatan yang dilakukan secara terus menerus oleh pimpinan dan seluruh pegawai untuk memberikan keyakinan memadai atas tercapainya tujuan organisasi melalui kegiatan yang efektif dan efisien, keandalan pelaporan keuangan, pengamanan aset negara, dan ketaatan terhadap peraturan perundang-undangan. Dengan ditaati dan dilaksanakannya sistem pengendalian internal pemerintah diharapkan dapat mengendalikan secara positif seluruh aktivitas kegiatan dalam penyelenggaraan pemerintahaan khususnya dalam penyelenggaraan penatausahaan aset tetap. Hal tersebut didukung oleh hasil penelitian yang dilakukan oleh (Subrata, I. W., Yasa, G. W., \& Astika, 2018); (Wahyuni, R., Fadah., Tobing, 2018); dan (Goutama, E., 2019) menyatakan bahwa SPIP berpengaruh secara positif dan signifikan terhadap penatausahaan aset tetap. Sehingga pelaksanaan SPIP yang semakin sesuai dengan peraturan maka akan menghasilkan penatausahaan aset tetap yang lebih baik.

Pengaruh Pemanfaatan TI Terhadap Kualitas LKPD Melalui Penatausahaan Aset Tetap

Hasil uji hipotesis keenam dihasilkan pemanfaatan TI berpengaruh positif terhadap kualitas LKPD melalui penatausahaan aset tetap. Uji analisis jalur dan uji sobel, menghasilkan pemanfaatan TI berpengaruh secara tidak langsung terhadap kualitas LKPD melalui penatausahaan aset tetap dengan nilai t-hitung pada uji sobel sebesar 2,577 lebih besar dari t-tabel 1,684, sehingga disimpulkan penatausahaan aset tetap memenuhi syarat sebagai variabel intervening atau dapat memediasi pengaruh 
pemanfaatan TI terhadap kualitas LKPD. Hasil tersebut menunjukkan pengaruh tidak langsung pemanfaatan TI terhadap kualitas LKPD lebih besar dibandingkan dengan pengaruh langsung pemanfaatan TI terhadap kualitas LKPD. Hal ini berarti bahwa penatausahaan aset tetap mempunyai peranan yang sangat penting dalam menentukan kualitas LKPD sehingga diperlukan pemanfaatan TI secara maksimal agar lebih meningkatkan pelaksanaaan penatausahaan aset tetap secara tertib sebagai upaya peningkatan kualitas LKPD.

Hasil ini sejalan dengan (Rachmawati, R., Arwati., 2018) yang menunjukan adanya pengaruh positif dan signifikan pemanfaatan TI terhadap efektivitas penatausahaan aset tetap pada Pemkab Garut. Penelitian ini didukung juga oleh (Febrianti, 2016) yang menyatakan bahwa penatausahaan aset tetap memiliki pengaruh positif dan signifikan terhadap kualitas LKPD pada Pemerintah Kabupaten Kubu Raya.

Pengaruh SPIP Terhadap Kualitas LKPD Melalui Penatausahaan Aset Tetap

Hasil uji hipotesis ketujuh dihasilkan SPIP berpengaruh positif terhadap kualitas LKPD melalui penatausahaan aset tetap. Uji analisis jalur dan uji sobel, menghasilkan SPIP berpengaruh secara tidak langsung terhadap kualitas LKPDmelalui penatausahaan aset tetap dengan nilai t-hitung pada

\section{KESIMPULAN DAN SARAN}

\section{Simpulan}

Atas hasil dan pembahasan penelitian diatas, maka penulis dapat menarik beberapa kesimpulan sebagai berikut :

1. SPIP dan penatausahaan aset tetap berpengaruh positif dan signifikan terhadap kualitas LKPD. artinya apabila SPIP dan penatausahaan aset tetap dapat terlaksana sesuai dengan peraturan, maka kualitas LKPD dapat diwujudkan. Sementara, Pemanfaatan TI berpengaruh positif namun tidak signifikan terhadap kualitas LKPD. artinya pemanfaatan TI tidak menjamin akan baiknya kualitas LKPD yang dihasilkan.

2. Pemanfaatan TI dan SPIP berpengaruh positif dan signifikan terhadap penatausahaan aset tetap. artinya apabila pemanfaatan TI dan SPIP dapat dipergunakan secara maksimal maka penatausahaan aset tetap dapat terlaksana sesuai harapan. uji sobel sebesar 2,577 lebih besar dari t-tabel 1,684, sehingga disimpulkan penatausahaan aset tetap memenuhi syarat sebagai variabel intervening atau dapat memediasi pengaruh sistem pengendalian internal pemerintah terhadap kualitas laporan keuangan pemerintah daerah. Hasil tersebut menunjukkan pengaruh tidak langsung SPIP terhadap kualitas laporan keuangan pemerintah lebih besar dibandingkan dengan pengaruh langsung SPIP terhadap kualitas laporan keuangan pemerintah. Hal ini berarti bahwa penatausahaan aset tetap mempunyai peranan yang sangat penting dalam menentukan kualitas LKPD sehingga diperlukan pelaksanaan SPIP yang benar agar lebih meningkatkan pelaksanaaan penatausahaan aset tetap secara tertib sebagai upaya peningkatan kualitas LKPD.

Hasil ini sejalan dengan (Trisnani, E. D., Dimyati, M., \& Paramu, 2018) yang menunjukan adanya pengaruh positif dan signifikan SPIP terhadap keandalan laporan keuangan dengan menggunakan mediasi penatausahaan aset tetap pada Pemkab Bondowoso. Selain itu, (Mansur, 2018) menyatakan bahwa optimalisasi manajemen aset memiliki pengaruh positif dan signifikan terhadap kualitas LKPD pada Pemkab Taliabu.

3. Pengaruh tidak langsung TI dan SPIP terhadap kualitas LKPD dengan mediasi penatausahaan aset tetap lebih besar dibandingkan dengan pengaruh langsung pemanfaatan TI dan SPIP terhadap kualitas LKPD. Hal ini menandakan penatausahaan aset tetap memiliki peranan yang lebih penting dalam mempengaruhi kualitas LKPD daerah dibandingkan pengaruh langsungnya.

\section{Saran}

Atas kesimpulan dalam penelitian, maka penulis memberikan beberapa saran sebagai berikut

1. Bagi BPKA Kota Bandung, disarankan agar terus meningkatkan kualitas LKPD dengan menyelesaikan permasalahan LKPD yang menjadi catatan BPK selama ini. Hal tersebut dapat terwujud apabila SPIP di BPKA terlaksana sesuai peraturan serta memaksimalkan pemanfaatan TI masa kini 
agar menunjang kinerja pada setiap pegawai dalam penatausahaan aset tetap.

2. Bagi Pemerintah Daerah Kota Bandung, peneliti menyarankan untuk:

a. Membenahi teknologi informasi pada setiap SKPD agar lebih terintegrasi dengan seluruh instansi terkait agar kualitas data yang dihasilkan dapat lebih lengkap dan akurat.

b. Mengevaluasi SPIP pada seluruh SKPD di lingkungan Pemerintah Daerah Kota Bandung agar segala bentuk permasalahan yang menjadi catatan BPK selama ini dapat segera diselesaikan dengan semestinya.

3. Peneliti selanjutnya dapat mengembangkan dengan menambah variabel penelitian seperti perilaku pemimpin, budaya organisasi, komitmen pimpinan, dan lain sebagainya. Agar diperoleh informasi yang lebih kuat dan akurat mengenai fenomena yang terjadi terkait kualitas LKPD.

\section{DAFTAR PUSTAKA}

Alminanda, P., M. 2018. (2018). Peran Komitmen Organisasi Dalam Memoderasi Pengaruh Kompetensi Sumber Daya Manusia, Sistem Pengendalian Intern Dan Pemanfaatan Teknologi Informasi Terhadap Kualitas Laporan Keuangan Pemerintah Daerah. Jurnal Analisis Bisnis Ekonomi, 16(2).

Anggriawan, F., Yudianto, I. (2018). Factors Affecting Information Quality of Local Government Financial Statement. Journal of Accounting Auditing and Business, 1(1).

Ardianto, R., Eforis, C. (2019). Pengaruh Penerapan Standar Akuntansi Pemerintah, Pemanfaatan Teknologi Informasi, Kompetensi Sumber Daya Manusia, Penerapan Sistem Pengendalian Intern Pemerintah, Dan Sistem Akuntansi Keuangan Daerah Terhadap Kualitas Laporan Keuangan Pemerintah Daerah. Jurnal Bina Akuntansi, 6(1), 95-136.

Donaldson, L., \& Davis, J. H. (1991). Stewardship Theory or Agency Theory: CEO Governance and Shareholder Returns. Australian Journal of Management, 16(1), 4964

Ekayanti, S., Rifa'i, A, I. (2017). Determinants Effectiveness Fixed Asset Management of District Government on the Island of Lombok. International Journal of Business Management and Economic Research(IJBMER), 9(1).

Eriadi., Erlina., M. (2018). Determinant Analysis Of The Quality Of Local Government Financialstatements In North Sumatra With The Effectiveness Of Management Of Regional Property As A Mediator. . International Journal of Civil Engineering and Technology (IJCIET), 9(5), 1334-1346.
Keuangan Daerah, Kompetensi Aparatur Pemerintah Dan Pemanfaatan Teknologi Informasi Terhadap Kualitas Laporan Keuangan Dengan Sistem Pengendalian Internal Sebagai Variabel Moderasi. JRA TIRTAYASA, 4(2).

Febrianti, S. (2016). Analisis Pengaruh Penatausahaan Aset Tetap Terhadap Kualitas Laporan Keuangan Pemerintah Daerah Kabupaten Kubu Raya. Jurnal Ekonomi Manajemen, 10(1).

Fhadillah, S., Y. I. (2018). The Influence of Application Government Internal Control System, Asset Management and Human Resources Competencies to Financial Accountability. Journal of Accounting Auditing and Business, 1(1).

Goutama, E., Y. (2019). The Role of Government Internal Control Systems and Utilization of Information Technology in Quality Reports. Journal of Accounting Auditing and Business, Vol.2(1).

Hasdiana, Hasang, I. (2018). Pemanfaatan Teknologi Informasi Dan Sistem Pengendalian Intern Pemerintah Terhadap Kualitas Laporan Keuangan Pemerintah Daerah. Economos : Jurnal Ekonomi Dan Bisnis, 1(3).

Kurniati, E., Asmony, T., \& Santoso, B. (2017). Kemelut Penatausahaan Aset Tetap (Dulu Hingga Kini). Jurnal Akuntansi Multiparadigma, 8(3), 540-558.

Mahmudi. (2016). Analisis Laporan Keuangan Pemerintah Daerah (3rd ed.). Sekolah Tinggi Ilmu Manajemen YKPN.

Mainar., Darwanis., Abdullah, S. (2017). pengaruh sistem pengendalian intern, pemahaman regulasi, dan sistem informasi terhadap manajemen aset. Jurnal Akuntasi Pascasarjana Universitas Syiah Kuala.

Mansur, I. (2018). The Influence Of Asset Inventory, Quality Of Human Resources And Leadership Commitment To Optimization Of Asset Management And Quality Of Financial Statements Regional Government Of Taliabu Islands Regency. Jurnal Ilmiah Administrasi Pemerintahan Daerah, $X(2)$.

Mardinan, T., Dahlan., F. (2018). Effect of Human Resources, Leadership Style, The Use of Information Technology and Internal Control on the Quality of Financial Statements. Journal of Accounting Auditing and Business, 1(1).

Mene, R., Karamoy, H., Warongan, J. (2018). Pengaruh Pemanfaatan Teknologi Informasi Dan Penerapan Sistem Pengendalian Intern Pemerintah Terhadap Kualitas Laporan Keuangan Pemerintah Daerah Kabupaten Halmahera Utara. Jurnal Riset Akuntansi Going Concern, 13(3), 133-143.

Muda, I., W. (2019). The Influence Of Human Resources Competency And The Use Of Information Technology On The Quality Of Local Government Financial Report With Regional Accounting System As An Intervening. Journal of Theoretical and Applied Information Technology, 95(20).

Nurillah, A., M. (2014). . Pengaruh Kompetensi Sumber Daya Manusia, Penerapan Sistem Akuntansi Keuangan Daerah (SAKD), Pemanfaatan Teknologi Informasi, Dan Sistem Pengendalian Intern Terhadap Kualitas Laporan Keuangan Pemerintah Daerah. Journal of Accounting, 3(2).

Nurlis, \& Yudiati, W. (2017). The Influence of Internal 
Control Effectiveness , Information Technology Utilization and Human Resources Competence on Local Government Financial Reporting Quality ( Survey on SKPD Banten Provincial Government and Serang City ). ). Research Journal of Finance and Accounting, 8(12), 111-124.

Putra, R., Azlina., Safitri, D. (2017). Pengaruh Kualitas Sumber Daya Manusia, Pemanfaatan Teknologi Informasi, Sistem Pengendalian Intern, Pengawasan Keuangan Daerah, Dan Komitmen Manajemen Terhadap Keandalan Pelaporan Keuangan Pemerintah. JOM Fekon, 4(1).

Rachmawati, R., Arwati., H. (2018). Optimalisasi Penggunaan Teknologi Informasi dalam Penatausahaan Asset/ Barang Milik Daerah. Jurnal Aset (Akuntansi Riset), 10(2), 189-197.

Raharjo, E. (2007). Agency Theory Vs Stewardship Theory in the Accounting Perspective. Fokus Ekonomi, 2(1), 3746.

Subrata, I. W., Yasa, G. W., \& Astika, I. B. P. (2018). Pengaruh Sistem Pengendalian Intern, Kemampuan Sumber Daya Manusia Dan Pemanfaatan Teknologi Informasi Pada Kualitas Laporan Barang Milik Daerah. E-Jurnal Ekonomi Dan Bisnis Universitas Udayana, 2, 477.

Trisnani, E. D., Dimyati, M., \& Paramu, H. (2018). Pengaruh Sistem Pengendalian Intern Terhadap Keandalan Laporan Keuangan Dengan Mediasi Penatausahaan Aset Tetap. Bisma, 11(3), 271.

Wahyuni, R., Fadah., Tobing, D. (2018). Pengaruh Kompetensi Sumber Daya Manusia Dan Pemanfaatan Teknologi Informasi Terhadap Kualitas Laporan Keuangan Melalui Pengelolaan Barang Milik Daerah. Jurnal Bisnis Dan Manajemen, 12(1), 66-80.

Wardani, D., Andriyani, I. (2017). Pengaruh Kualitas Sumber Daya Manusia, Pemanfaatan Teknologi Informasi, Dan Sistem Pengendalian Intern Terhadap Keandalan Pelaporan Keuangan Pemerintahan Desa Di Kabupaten Klaten. Jurnal Akuntansi, 5(2).

Wijana, N. (2007). Pemanfaatan Teknologi Informasi dan pengaruhnya pada kinerja individual pada bank perkreditan rakyat di kabupaten tabanan. Jurnal. Universitas Udayana. 